\title{
Diagnostic potential of methylated DAPK in brushing samples of nasopharyngeal carcinoma
}

This article was published in the following Dove Press journal:

Cancer Management and Research

\author{
Jian Zhang' \\ Zhisen Shen' \\ Huigao Liu $^{2}$ \\ Shuai Liu $^{3}$ \\ Wenxiu Shu ${ }^{4}$ \\ 'Department of Otorhinolaryngology \\ Head and Neck Surgery, Ningbo \\ Medical Center Lihuili Hospital, \\ Ningbo, People's Republic of China; \\ 2Department of Otorhinolaryngology \\ Head and Neck Surgery, Ningbo \\ Zhenhai Longsai Hospital, Ningbo, \\ People's Republic of China; \\ ${ }^{3}$ Department of Radiology, Ningbo \\ Medical Center Lihuili Eastern \\ Hospital, Ningbo, People's Republic of \\ China; ${ }^{4}$ Department of Oncology and \\ Hematology, Ningbo Medical Center \\ Lihuili Eastern Hospital, Ningbo, \\ People's Republic of China
}

Correspondence: Wenxiu Shu Department of Oncology and Hematology, Ningbo Medical Center Lihuili Eastern Hospital, No. I I I I JiangNan Road, Ningbo, Zhejiang, People's Republic of China Email teengle@I26.com
Background: The death-associated protein kinase $(D A P K)$ gene is an important member of the apoptotic pathway and is inactivated by abnormal methylation in numerous cancers, including nasopharyngeal carcinoma (NPC). However, the diagnostic value of DAPK methylation in brushing samples and tissue samples of NPC remains unclear.

Methods: We conducted a systematic meta-analysis based on 17 studies (including 386 tissue cases, 233 brushing cases, and 296 blood cases).

Results: Our results revealed an association between methylated DAPK and increased risk of NPC in blood, brushing, and tissue samples. In addition, the comparison of the pooled sensitivity, specificity, and area under the curve of methylated $D A P K$ in brushing and tissue samples demonstrated the non-inferior effectiveness of methylated $D A P K$ in brushing samples to monitor the development of NPC.

Keywords: death-associated protein kinase, methylation, nasopharyngeal carcinoma, diagnosis

\section{Introduction}

Nasopharyngeal carcinoma (NPC) is a cancer arising from the epithelial cells lining the nasopharynx. It has a wide geographic and racial distribution worldwide. The occurrence of NPC is rare in most parts of the world, but not in People's Republic of China. It is endemic in southern People's Republic of China, including Hong Kong, with a reported annual incidence of up to 50 cases per 100,000 people. ${ }^{1}$ Approximately 60,000 new NPC cases and 34,100 deaths from NPC were projected to occur in 2015 in People's Republic of China. ${ }^{2}$

As in other major human cancers, the progression of NPC is a multistep process involving interactions between multiple factors, including Epstein-Barr virus (EBV) infection,,${ }^{3,4}$ consumption of salted food, ${ }^{5-7}$ cigarette smoking, ${ }^{8,9}$ and alcohol consumption. ${ }^{10,11}$ Among these, EBV infection is necessary for NPC progression. By adulthood, approximately $90 \%$ of individuals are EBV infected. ${ }^{12,13}$ Although EBV is a ubiquitous pathogen, EBV-associated NPC develops in only a small fraction of infected individuals. Thus, it is believed that genetic factors may contribute significantly to the high risk of NPC in this population. To determine the differences present in the subset of EBV-positive individuals who develop cancer, multiple genome-wide studies have examined genetic and epigenetic abnormalities in specific oncogenes and tumor suppressor genes (TSGs) ${ }^{14-16}$ In recent years, promoter methylation has been recognized as a common mechanism of inactivating TSGs in the tumorigenesis of NPC. ${ }^{17,18}$ Because DNA hypermethylation is one of the earliest molecular alterations during malignant 
transformation in human epithelial cells and often occurs earlier than the morphological abnormalities of cancers, ${ }^{19,20}$ the analysis of promoter methylation of TSGs may be a promising method for the detection of NPC.

Death-associated protein kinase (DAPK) is encoded by the $D A P K$ gene, which is a novel serine/threonine kinase required for interferon gamma-induced apoptotic cell death. ${ }^{21}$ Numerous cancer cell clones with highly aggressive metastatic behavior lack DAP kinase expression, whereas the clones with low metastatic capabilities express the protein. ${ }^{22,23}$ Restoration of DAP kinase in highly metastatic cancer cells can suppress the metastatic ability of these cancer cells. ${ }^{22}$ As a novel TSG, the expression of DAP kinase is repressed in several types of human cancers by hypermethylation in the promoter $\mathrm{CpG}$ region of the gene, ${ }^{24,25}$ including in NPC. ${ }^{26,27}$ However, the diagnostic power of $D A P K$ methylation in NPC has not been investigated.

In the current study, we performed a meta-analysis of 17 studies to assess the association of $D A P K$ methylation with the risk of NPC and implemented a diagnostic meta-analysis to evaluate the diagnostic potential of $D A P K$ methylation for NPC.

\section{Materials and methods}

\section{Literature search strategy}

We performed a comprehensive literature search from a range of electronic databases, including PubMed, Embase, Google Scholar, and Web of Science (last search updated in January 2018) without language restrictions. The following search keywords were used: ("methylation" or "DNA methylation" or "promoter methylation" or "demethylation" or "hypermethylation") and ("nasopharyngeal cancer" or "nasopharyngeal neoplasm" or "nasopharyngeal carcinoma" or "NPC") and (“DAPK" or "death associated protein kinase").

\section{Selection criteria}

The following predefined criteria were used to evaluate the eligibility of included studies: 1) the study design must be a case-control study focused on the association between $D A P K$ promoter methylation and NPC patients and 2) the study must provide sufficient information about $D A P K$ promoter methylation to calculate odds ratio (OR) and 95\% CI. The study was excluded if it did not meet the inclusion criteria. If the authors had published multiple studies using the same population, only the most recent or the largest-sample-size publication was used in our meta-analysis.

\section{Data extraction}

All the relevant data of the eligible studies were retrieved independently by all the authors of this study. The follow- ing information was extracted: the first author's name, the published year, the race distribution of the study subjects, the source of the samples, the number of participants, and the frequency of $D A P K$ methylation.

\section{Statistical analysis}

The strength of the association between methylated $D A P K$ and the risk of NPC is represented by the pooled overall OR across all the eligible studies. The heterogeneity of all eligible studies was quantified with the $I^{2}$ statistic and $\chi^{2}$ test with the corresponding $P$-value. ${ }^{28}$ A DerSimonian-Laird $(\mathrm{D}+\mathrm{L})$ model was applied to calculate pooled ORs when there existed heterogeneity in the meta-analysis $\left(I^{2}>50 \%, \chi^{2}\right.$ test with $P<0.05)$. Otherwise, a Mantel-Haenszel (M-H) model was used. ${ }^{28}$ A meta-regression was performed to identify the source of heterogeneity. Sensitivity analysis was performed to assess the stability of our results by omitting single studies in the meta-analysis iteration to determine the effect of the individual data on the overall pooled OR. The stability of our results was tested by switching between the $\mathrm{D}+\mathrm{L}$ and M-H models. Publication bias was quantitatively estimated by Egger's linear regression test.

For the diagnostic meta-analysis, pooled sensitivity, specificity, positive likelihood ratio (PLR), negative likelihood ratio (NLR), diagnostic odds ratio (DOR), and their corresponding $95 \%$ CIs were calculated. The PLR is calculated as sensitivity/(1-specificity), and the NLR is calculated as (1-sensitivity)/specificity. The DOR is a measure that combines sensitivity and specificity and is calculated as PLR/ NLR. ${ }^{29}$ The Fagan plots, assessing the clinical utility of a tested indicator, were drawn based on the values of PLR and NLR. We evaluated pre-test probabilities of $25 \%$ and $50 \%$ versus corresponding post-test probabilities. ${ }^{30}$ Summary receiver operation characteristic curves (SROCs) with the area under the receiver operating characteristic curve (AUC) were generated. All the data analyses were accomplished by STATA-12.0 software (Stata Corporation, College Station, TX, USA). All $P$-values were two sided, and a $P$-value less than 0.05 was deemed significant.

\section{Results \\ Study characteristics}

First, 311 articles were collected by electronic searches in PubMed, Embase, Google Scholar, and Chinese National Knowledge Infrastructure. The selection process of eligible studies is illustrated in Figure 1. After carefully filtering all the potential papers according to the selection criteria, a total of 17 studies were included in the meta-analysis. Among 


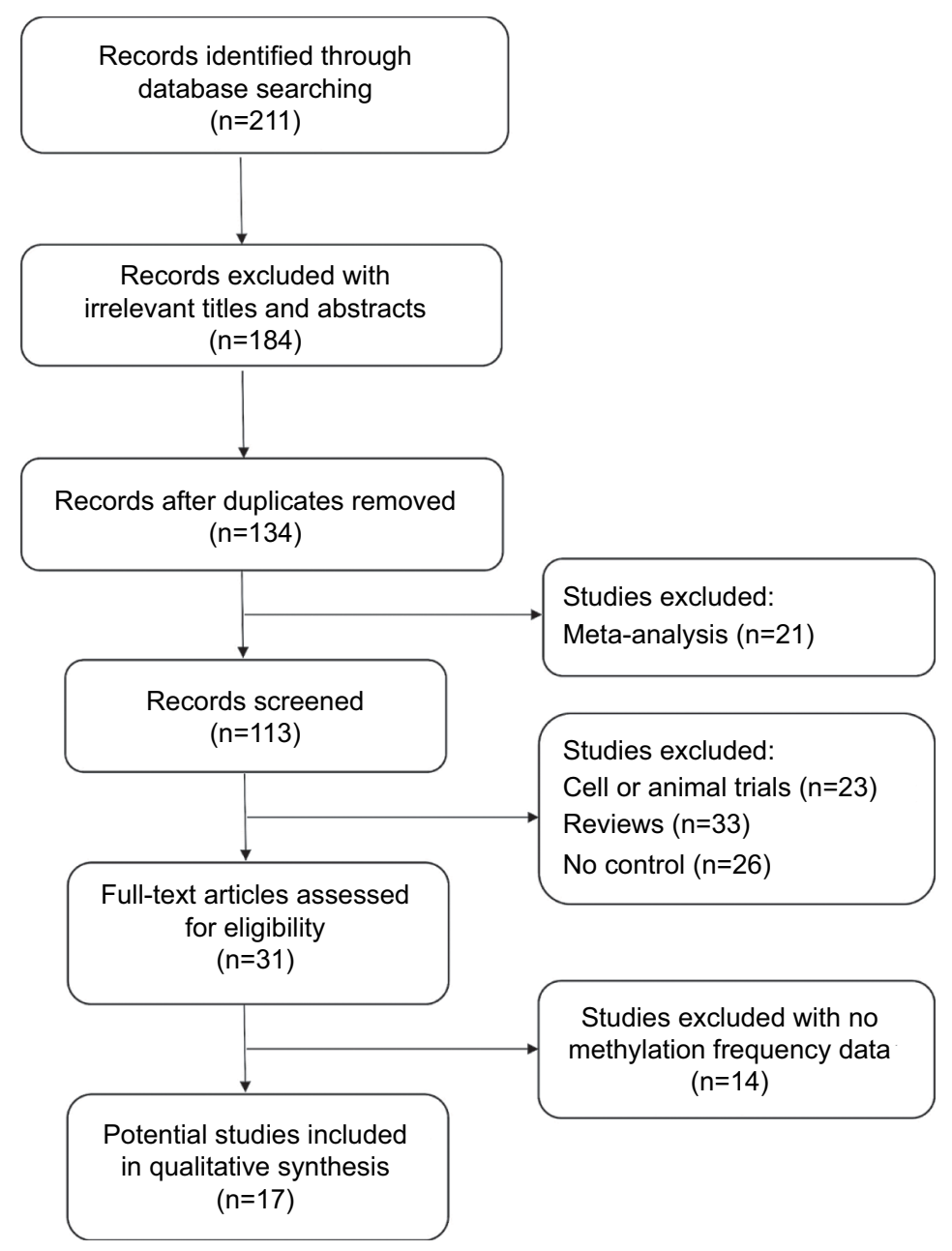

Figure I Flow diagram of the literature selection process.

them, three studies evaluated the association between $D A P K$ methylation and the risk of NPC using blood samples, ${ }^{31-33}$ and five studies used brushing samples. ${ }^{33-36}$ Nine other studies assessed the correlation of $D A P K$ methylation and the risk of NPC using NPC and non-tumorous tissue samples. ${ }^{17,26,27,35-40}$ Table 1 shows the main characteristics of the included studies.

\section{Association of DAPK methylation in NPC and controls}

We assessed the difference in $D A P K$ methylation between NPC and normal controls in the 17 studies, which included 915 NPC patients and 404 controls. As there was heterogeneity across studies $\left(I^{2}=54.7 \%, P=0.004\right)$, we changed the fixed-effects model (M-H) and random-effects model (D+L) to affirm the reliability of our results $\left(\mathrm{OR}_{(\mathrm{M}-\mathrm{H})}=13.82,95 \%\right.$ CI: [9.13, 20.92]; $\left.\mathrm{OR}_{(\mathrm{D}+\mathrm{L})}=17.72,95 \% \mathrm{CI}:[8.45,37.14]\right)$. Besides, sensitivity analysis was also performed to support the robustness of our results (Table 2). The pooled ORs strongly suggested that $D A P K$ methylation was associated with increased risk of NPC (Figure 2). Egger's test revealed no evidence of publication bias $(P=0.58$; Figure 3$)$.

\section{Subgroup analysis of DAPK methylation in NPC and controls}

To ascertain the source of heterogeneity, a meta-regression was performed. Our results attributed the heterogeneity to the three studies on Caucasians (Table 3). Therefore, subgroup analyses by ethnicity were conducted. As seen in Figure 4A, a significant decrease was observed in heterogeneity after exclusion of the three studies on Caucasians $\left(I^{2}=0.0 \%, P=\right.$ 0.58 , Figure 4A). Additionally, the pooled OR illustrated the association of $D A P K$ methylation and elevated risk of NPC $\left(\mathrm{OR}_{(\mathrm{M}-\mathrm{H})}=20.93,95 \% \mathrm{CI}:[12.64,34.64]\right)$.

In addition, we performed a subgroup analysis by sample type, and the results showed that the pooled OR 
Table I General characteristics of studies included in the current meta-analysis

\begin{tabular}{|c|c|c|c|c|c|c|}
\hline Author & Year & Country & Ethnicity & Sample type & Case, N (M, \%) & Control, N (M, \%) \\
\hline Kwong et $\mathrm{al}^{17}$ & 2002 & People's Republic of China & Asian & Tissue & $33(72.72 \%)$ & $6(0.00 \%)$ \\
\hline Liang et $\mathrm{a}^{39}$ & 2015 & People's Republic of China & Asian & Tissue & $48(75.00 \%)$ & $26(0.00 \%)$ \\
\hline Wonget $\mathrm{a}^{40}$ & 2002 & People's Republic of China & Asian & Tissue & $32(75.00 \%)$ & $5(0.00 \%)$ \\
\hline Zhang et a ${ }^{36}$ & 2012 & People's Republic of China & Asian & Tissue & $49(67.35 \%)$ & $20(0.00 \%)$ \\
\hline Nawaz et $\mathrm{al}^{27}$ & 2015 & Morocco & Caucasian & Tissue & $44(25.00 \%)$ & $18(27.78 \%)$ \\
\hline Kong et $\mathrm{a}^{38}$ & 2006 & People's Republic of China & Asian & Tissue & $46(76.00 \%)$ & $6(0.00 \%)$ \\
\hline Fendri et $\mathrm{a}^{26}$ & 2009 & Tunisia & Caucasian & Tissue & $68(88.24 \%)$ & $9(0.00 \%)$ \\
\hline Challouf et $\mathrm{al}^{37}$ & 2012 & Tunisia & Caucasian & Tissue & $36(47.22 \%)$ & $19(15.79 \%)$ \\
\hline Chang et $\mathrm{al}^{35}$ & 2003 & People's Republic of China & Asian & Tissue & 30 (76.67\%) & $6(0.00 \%)$ \\
\hline Tong et $\mathrm{al}^{34}$ & 2002 & People's Republic of China & Asian & Brushing & $28(50.00 \%)$ & $12(0.00 \%)$ \\
\hline Yang et $\mathrm{al}^{33}$ & 2015 & People's Republic of China & Asian & Brushing & 96 (68.75\%) & $43(18.60 \%)$ \\
\hline Chang et $\mathrm{a}^{35}$ & 2003 & People's Republic of China & Asian & Brushing & $30(50.00 \%)$ & $43(2.33 \%)$ \\
\hline Zhang et a ${ }^{36}$ & 2012 & People's Republic of China & Asian & Brushing & $49(55.10 \%)$ & $20(0.00 \%)$ \\
\hline Chang et $\mathrm{a}^{35}$ & 2003 & People's Republic of China & Asian & Brushing & $30(63.33 \%)$ & $37(0.00 \%)$ \\
\hline Yang et $\mathrm{a}^{33}$ & 2015 & People's Republic of China & Asian & Blood & $220(27.27 \%)$ & $50(4.00 \%)$ \\
\hline Wong et $\mathrm{a}^{32}$ & 2004 & People's Republic of China & Asian & Blood & $41(19.51 \%)$ & $43(0.00 \%)$ \\
\hline Tian et $\mathrm{al}^{31}$ & 2013 & People's Republic of China & Asian & Blood & $35(51.43 \%)$ & $4 \mathrm{l}(9.76 \%)$ \\
\hline
\end{tabular}

Abbreviation: M, Methylation.

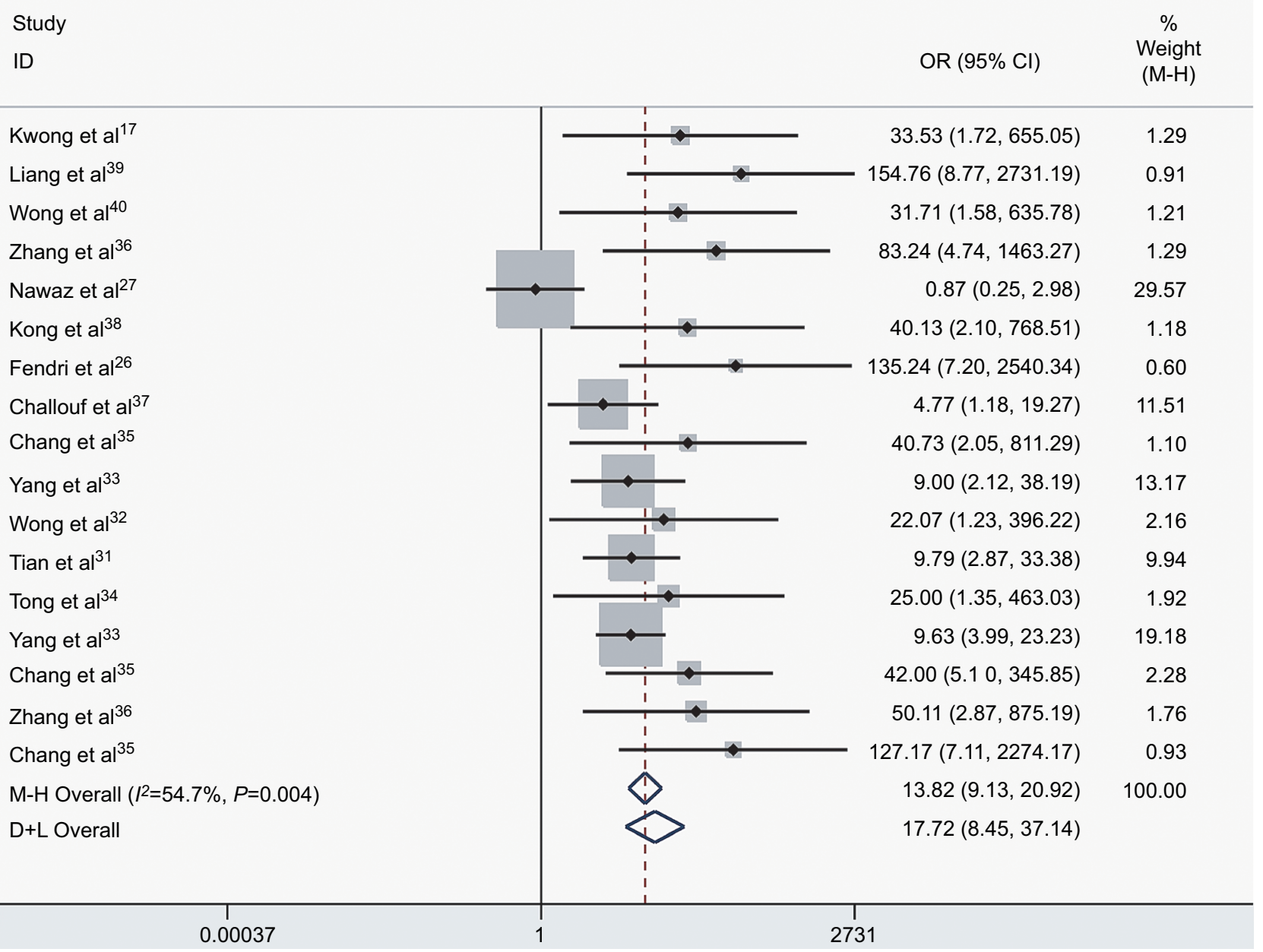

Figure 2 The forest plot for the association between DAPK methylation and the risk of NPC by the fixed-effects model (M-H) and random-effects model (D+L) in NPC vs controls.

Abbreviations: NPC, nasopharyngeal carcinoma; M-H, Mantel-Haenszel; D+L, DerSimonian-Laird; OR, odds ratio; Cl, confidence interval. 
Table 2 Sensitivity analysis of pooled OR for DAPK methylation between NPC and controls

\begin{tabular}{|c|c|c|}
\hline Study omitted & Year & Estimated OR $(95 \% \mathrm{Cl})$ \\
\hline Kwong et al ${ }^{17}$ & 2002 & $17.44(8.10,37.54)$ \\
\hline Liang et $\mathrm{a}^{39}$ & 2015 & $15.65(7.52,32.57)$ \\
\hline Wong et $\mathrm{a}^{40}$ & 2002 & $17.50(8.12,37.69)$ \\
\hline Zhang et a ${ }^{36}$ & 2012 & $16.39(7.74,34.71)$ \\
\hline Nawaz et $\mathrm{al}^{27}$ & 2015 & $17.21(10.20,29.06)$ \\
\hline Kong et $\mathrm{a}^{138}$ & 2006 & $17.25(8.03,37.08)$ \\
\hline Fendri et $\mathrm{a}^{26}$ & 2009 & I5.94 (7.59, 33.45) \\
\hline Challouf et $\mathrm{al}^{37}$ & 2012 & $20.49(9.27,45.297)$ \\
\hline Chang et $\mathrm{a}^{35}$ & 2003 & $17.25(8.03,37.07)$ \\
\hline Yang et $\mathrm{al}^{33}$ & 2015 & $19.64(8.73,44.18)$ \\
\hline Wong et $\mathrm{a}^{32}$ & 2004 & $17.82(8.25,38.53)$ \\
\hline Tian et $\mathrm{al}^{31}$ & 2013 & $19.75(8.68,44.92)$ \\
\hline Tong et $\mathrm{a}^{34}$ & 2002 & $|7.7|(8.19,38.23)$ \\
\hline Yang et $\mathrm{al}^{33}$ & 2015 & 20.40 (8.7I, 47.79) \\
\hline Chang et $\mathrm{a}^{35}$ & 2003 & I6.82 (7.79, 36.32) \\
\hline Zhang et a ${ }^{36}$ & 2012 & $16.96(7.93,36.287)$ \\
\hline Chang et $\mathrm{a}^{35}$ & 2003 & $15.92(7.59,33.36)$ \\
\hline
\end{tabular}

Abbreviations: OR, odds ratio; NPC, nasopharyngeal carcinoma.

Table 3 Meta-regression analysis of DAPK methylation in NPC vs controls

\begin{tabular}{llll}
\hline Characteristics & Coefficient & $\boldsymbol{P}$ & $\mathbf{9 5 \%} \mathbf{~ C l}$ \\
\hline $\begin{array}{l}\text { Year } \\
\text { Ethnicity }\end{array}$ & -0.053 & 0.57 & $(-0.26,0.15)$ \\
$\quad \begin{array}{l}\text { Caucasian } \\
\text { Sample type }\end{array}$ & -2.37 & 0.043 & $(-4.79,0.058)$ \\
$\quad$ Blood & -0.67 & 0.51 & $(-2.83,1.48)$ \\
$\quad \begin{array}{l}\text { Tissue } \\
\text { Method }\end{array}$ & 0.39 & 0.69 & $(-1.75,2.52)$ \\
$\quad$ MS-HRM & -0.73 & 0.74 & $(-5.55,4.09)$ \\
$\quad$ MSP & -0.03 & 0.99 & $(-4.27,4.22)$ \\
\hline
\end{tabular}

Abbreviations: MS-HRM, methylation-sensitive high resolution melting; MSP, methylation specific PCR; NPC, nasopharyngeal carcinoma.

was 22.27 for tissue samples, 10.43 for blood samples, and 20.50 for brushing samples (tissue: $\mathrm{OR}_{(\mathrm{D}+\mathrm{L})}=22.27,95 \%$ CI [5.09, 97.55]; blood: $\mathrm{OR}_{(\mathrm{M}-\mathrm{H})}=10.43,95 \%$ CI [4.15, 26.20]; brushing: $\mathrm{OR}_{(\mathrm{M}-\mathrm{H})}=20.50,95 \% \mathrm{CI}[10.15,41.41]$; Figure 4B).

\section{Diagnostic value of DAPK methylation for NPC and controls}

As shown in Figure 4B, the pooled OR in tissue samples was congruent with that in brushing samples, implying that the $D A P K$ methylation in brushing samples may serve as a useful and noninvasive biomarker for NPC. However, the comparison of the diagnostic capability of $D A P K$ methylation for NPC in tissue samples and in brushing sample has not been investigated. Therefore, we performed a diagnostic meta-analysis of 9 studies on NPC tissue samples and a separate one of 5 studies on NPC brushing samples. The summary specificity and sensitivity of methylated $D A P K$ for distinguishing NPC from control tissue samples were 0.99 and $0.69(0.55-0.80)$, respectively (tissue: specificity $=$ $0.99,95 \%$ CI $[0.85,1.00]$; sensitivity $=0.69,95 \%$ CI $[0.55$, $0.80]$; Figure 5A). The summary specificity and sensitivity of methylated $D A P K$ for identification of NPC from control brushing samples were 0.98 and 0.58 , respectively (brushing: specificity $=0.98,95 \%$ CI $[0.85,1.00]$; sensitivity $=0.58$, 95\% CI [0.50, 0.67]; Figure 5B).

The SROCs based on specificity and sensitivity are shown in Figure 6. The AUC was 0.92 for tissue and 0.71 for brushing samples (tissue: AUC $=0.92,95 \%$ CI [0.90-0.94], Figure 6A; brushing: $\mathrm{AUC}=0.71,95 \% \mathrm{CI}[0.67,0.75]$, Figure 6B). In addition, the summary DOR, another diagnostic-strength parameter that indicates better diagnostic strength with higher values, was 184 for tissue and 87 for brushing (tissue: DOR $=184,95 \%$ CI $[9,3725]$; brushing: DOR $=87,95 \%$ CI $[9$, $865])$. There was no publication bias in this diagnostic metaanalysis (Figure 7).

The abovementioned results confirm that the detection of $D A P K$ methylation could serve as an auxiliary technology for the diagnosis of NPC. Therefore, it is necessary to evaluate the clinical value of $D A P K$ methylation during clinical practice. The PLR and NLR are effective indicators of clinical utility, as is the Fagan plot. The PLR and NLR for tissue were 58.8 and 0.32 , respectively (tissue: PLR $=58.8,95 \%$ CI [3.7, 930.0]; NLR $=0.32$, 95\% CI [0.21, 0.47]), while the PLR and NLR for brushing samples were 36.7 and 0.42 , respectively (brushing: PLR $=36.7,95 \%$ CI [3.7, 367.3]; $\mathrm{NLR}=0.42,95 \% \mathrm{CI}[0.35,0.51])$. As indicated by PLR in tissue, NPC patients had a nearly a 59 times higher chance of positive detection of $D A P K$ methylation than in control tissue samples. The NLR indicated that normal control tissue samples had a threefold greater chance (the reciprocal of the value of NLR) of having unmethylated $D A P K$ than NPC patients. The PLR and NLR for brushing samples indicated a nearly 37 times higher chance of positive detection of $D A P K$ methylation in NPC brushing samples than in controls and twofold greater chance of having unmethylated $D A P K$ in control brushing samples than in NPC patients.

The Fagan plot was generated for the visual presentation of the diagnostic performance of the detection of methylated $D A P K$. As shown in Figure 8A and B, when the prior probability was taken as $25 \%$ and $50 \%$, the Fagan plot illustrated that the probability of an individual being diagnosed with 


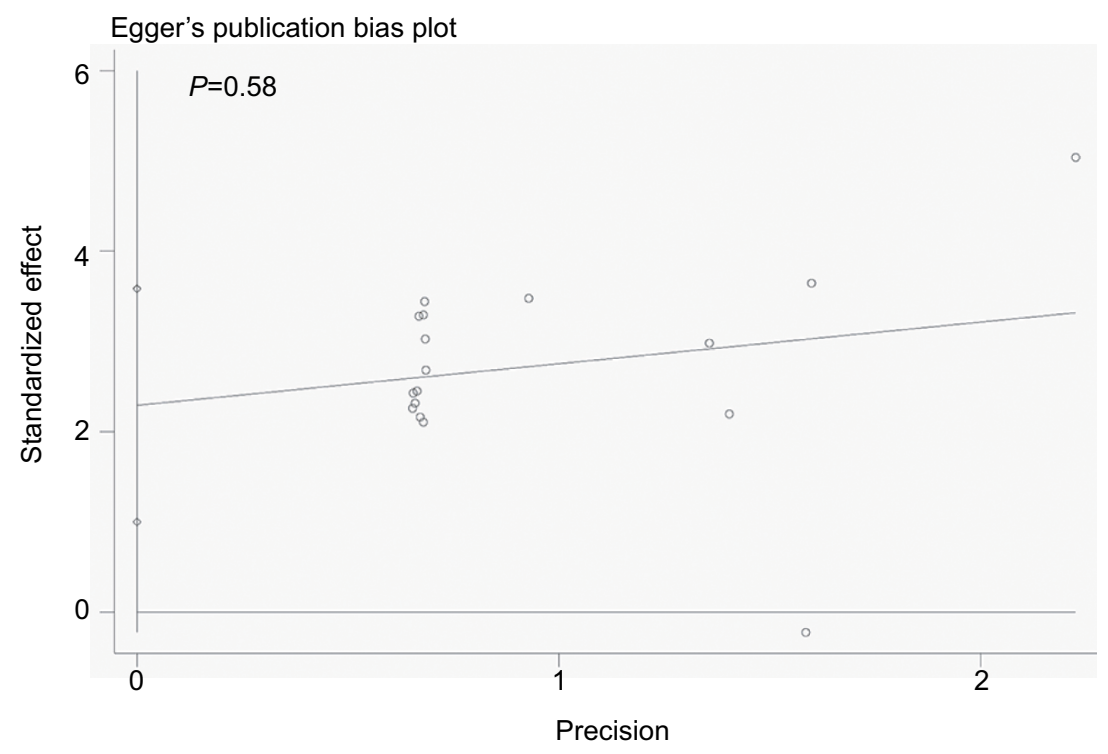

Figure 3 Egger's plot of publication bias for DAPK methylation in the current study.

A

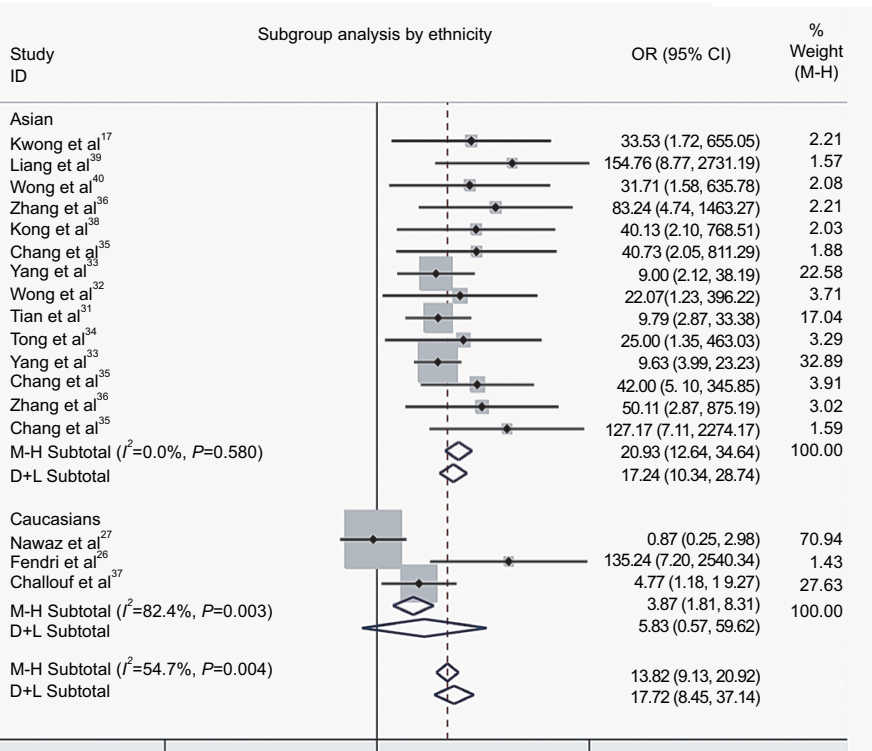

B

\begin{tabular}{|c|c|c|c|}
\hline \multicolumn{2}{|c|}{ Subgroup analysis by sample type } & OR $(95 \% \mathrm{Cl})$ & $\begin{array}{c}\% \\
\text { Weight } \\
\text { (M-H) }\end{array}$ \\
\hline $\begin{array}{l}\text { Tissue } \\
\text { Kwong et a } 1^{17}\end{array}$ & & & 2.65 \\
\hline $\begin{array}{l}\text { Kwong et al" } \\
\text { Liang et al }{ }^{39}\end{array}$ & & $-154.76(8.77,2731.19)$ & $\begin{array}{l}2.65 \\
1.88\end{array}$ \\
\hline Wong et al ${ }^{40}$ & & $31.71(1.58,635.78)$ & 2.49 \\
\hline Zhang et al ${ }^{36}$ & & $83.24(4.74,1463.27)$ & $\begin{array}{r}2.65 \\
60.76\end{array}$ \\
\hline Nawaz et $\mathrm{al}^{27}$ & & $\begin{array}{r}0.87(0.25,2.98) \\
40.13(2.10,768.51)\end{array}$ & $\begin{array}{r}6.16 \\
2.43\end{array}$ \\
\hline Kong et $\mathrm{al}^{38}$ & & $-135.24(7.20,2540.34)$ & 1.23 \\
\hline $\begin{array}{l}\text { ri et al }\left.\right|^{26} \\
\text { ouf et }\left.a\right|^{37}\end{array}$ & & $4.77(1.18,19.27)$ & 23.66 \\
\hline Chang et al ${ }^{35}$ & & $\begin{array}{r}40.73(2.05,811.29) \\
1200(654.2201)\end{array}$ & $\begin{array}{r}2.25 \\
100.00\end{array}$ \\
\hline $\begin{array}{l}\text { M-H Subtotal }\left(I^{2}=72.0 \%, P=0.000\right) \\
D+L \text { Subtotal }\end{array}$ & & $22.27(5.09,97.55)$ & \\
\hline Blood & & & \\
\hline $\begin{array}{l}\text { Yang et al }{ }^{33} \\
\text { Wong et al }^{32}\end{array}$ & & $\begin{array}{r}9.00(2.12,38.19) \\
22.07(1.23,396.22)\end{array}$ & 52.10 \\
\hline Tian et al ${ }^{31}$ & & $\begin{array}{r}2.0(1.23,396.22) \\
9.79(2.87,33.38)\end{array}$ & $\begin{array}{r}8.56 \\
39.33\end{array}$ \\
\hline M-H Subtotal $\left(I^{2}=0.0 \%, P=0.857\right)$ & & $\begin{array}{l}10.43(4.15,26.20) \\
1025(4.21 .24 .94)\end{array}$ & 100.00 \\
\hline & & & \\
\hline $\begin{array}{l}\text { Brushing } \\
\text { Tong et a }\left.\right|^{34}\end{array}$ & & 2500 & \\
\hline Yang et $\mathrm{al}^{33}$ & & $9.63(3.99,23.23)$ & $\begin{array}{r}73.30 \\
73.58\end{array}$ \\
\hline Chang et $\mathrm{al}^{35}$ & & $42.00(5.10,345.85)$ & 8.76 \\
\hline Zhang & & $50.11(2.87,875.19)$ & 6.75 \\
\hline Chang et $\mathrm{al}^{35}$ & & .127.17 (7.11, 2274.17) & 3.55 \\
\hline $\begin{array}{l}\text { M-H Subtotal }\left(I^{2}=23.2 \%, P=0.267\right) \\
D+L \text { Subtotal }\end{array}$ & & $\begin{array}{r}20.50(10.15,41.41) \\
21.88(7.93,60.36)\end{array}$ & 100.00 \\
\hline M-H Subtotal $\left(I^{2}=54.7 \%, P=0.004\right)$ & & $13.82(9.13,20.92)$ & \\
\hline$D+L$ Subtotal & & $17.72(8.45,37.14)$ & \\
\hline
\end{tabular}

Figure 4 The forest plots for the association of DAPK methylation and the risk of NPC by subgroup analyses.

Notes: (A) Subgroup analysis by ethnicity; (B) Subgroup analysis by sample type.

Abbreviations: NPC, nasopharyngeal carcinoma; OR, odds ratio; Cl, confidence interval; M-H, Mantel-Haenszel ; D+L, DerSimonian-Laird.

NPC was 95\% and 98\%, respectively, following a methylated $D A P K$ in tissue samples. However, the probability of an exclusion diagnosis of NPC was $16 \%$ and $26 \%$ following a non-methylated $D A P K$ in tissue samples. As illustrated in Figure $8 \mathrm{C}$ and D, with prior probabilities of $25 \%$ and $50 \%$, the Fagan plot illustrated that the probability of an individual being diagnosed with NPC was $93 \%$ and $97 \%$, respectively, following a methylated $D A P K$ in brushing samples. However, the probability of an exclusion diagnosis of NPC was $13 \%$ and 20\% following a non-methylated $D A P K$ in brushing samples. The results of our diagnostic meta-analysis imply that the detection of methylated $D A P K$ in brushing samples could serve as an effective biomarker for diagnosis of NPC.

\section{Discussion}

The incidence of NPC is rare in western populations, with rates below 2 per 100,000 person-years. ${ }^{41} \mathrm{NPC}$ is much more common in People's Republic of China and in the 


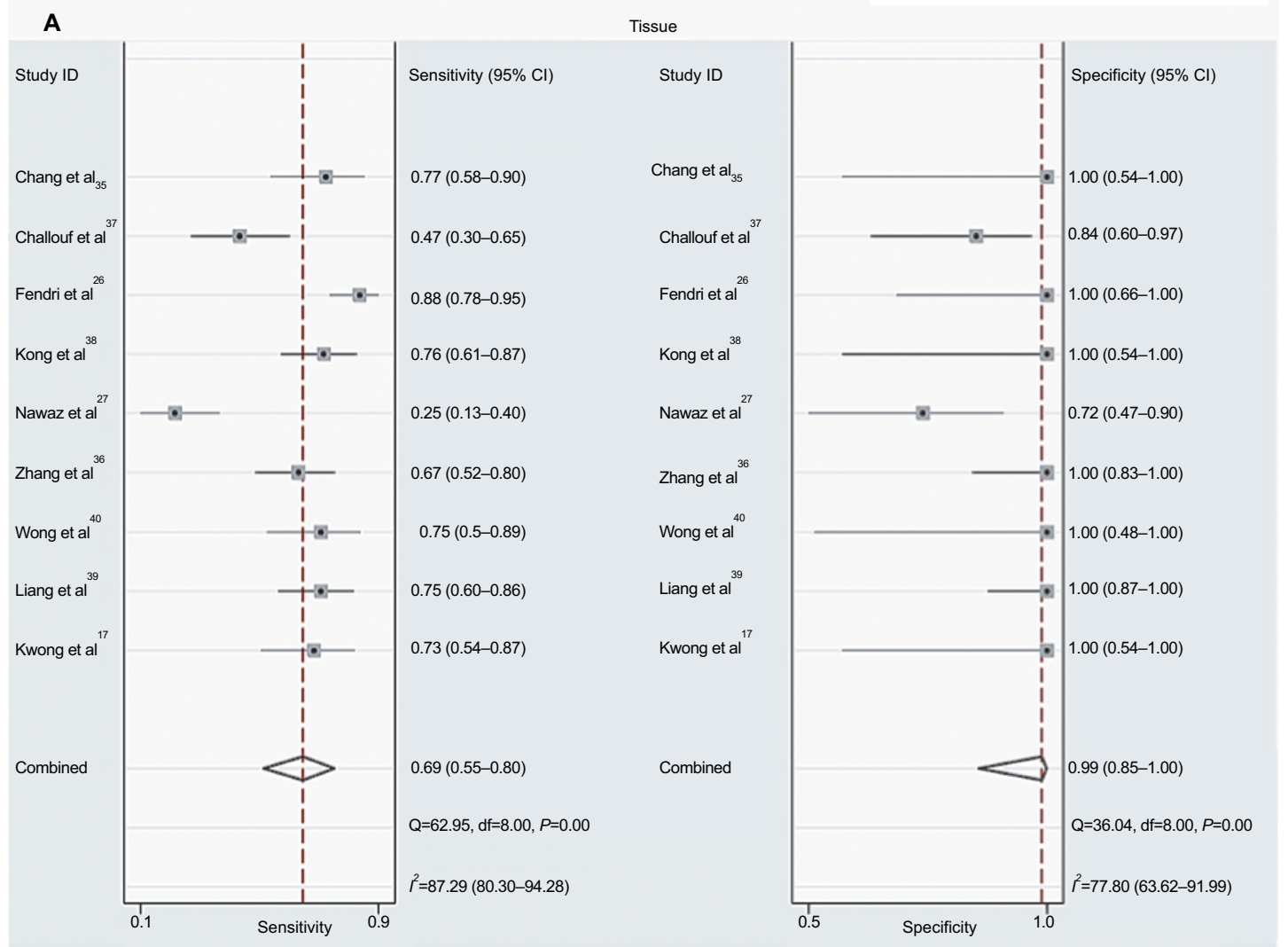

B

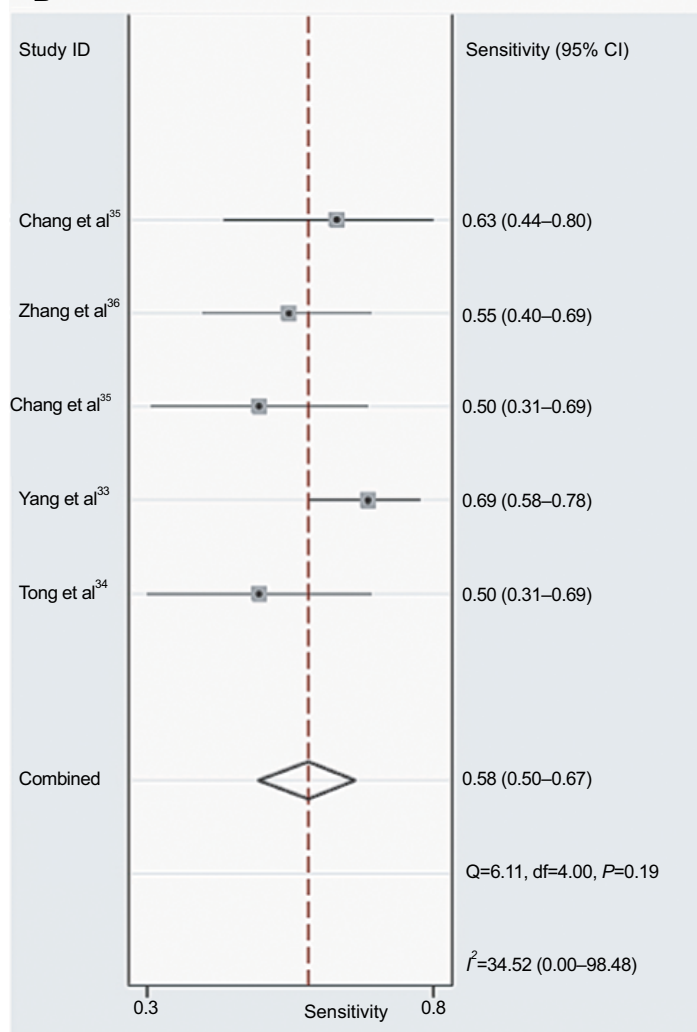

Brushing

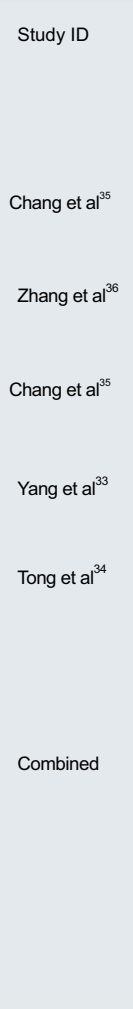

Specificity $(95 \% \mathrm{Cl})$

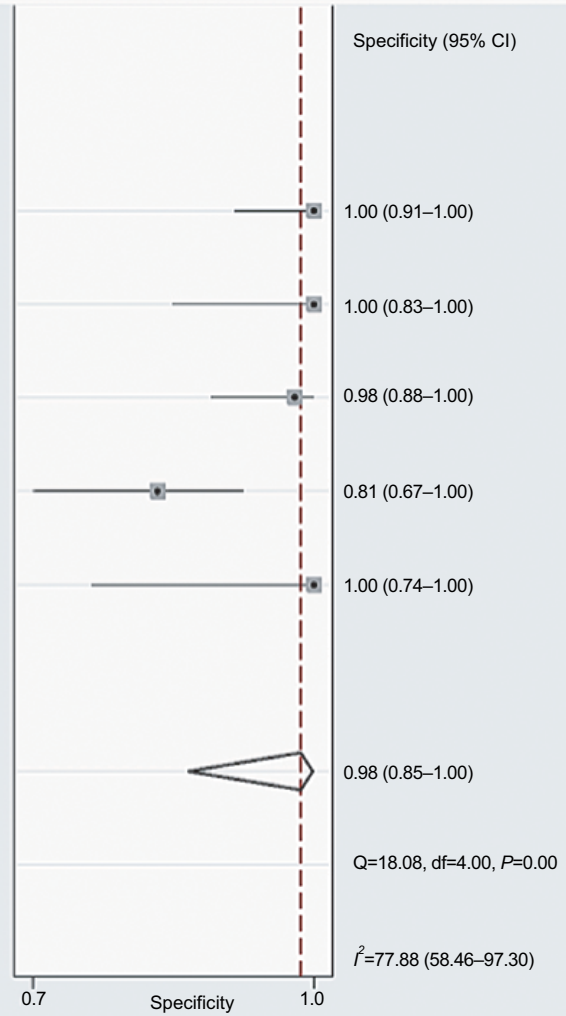

Figure 5: Forest sensitivity and specificity of methylated DAPK for diagnosis of NPC.

Notes: (A) Forest sensitivity and specificity of methylated DAPK for diagnosis of NPC using tissue sample; (B) Forest sensitivity and specificity of methylated DAPK for diagnosis of NPC using brushing sample.

Abbreviation: NPC, nasopharyngeal carcinoma; OR, odds ration; $\mathrm{Cl}$, confidence interval. 

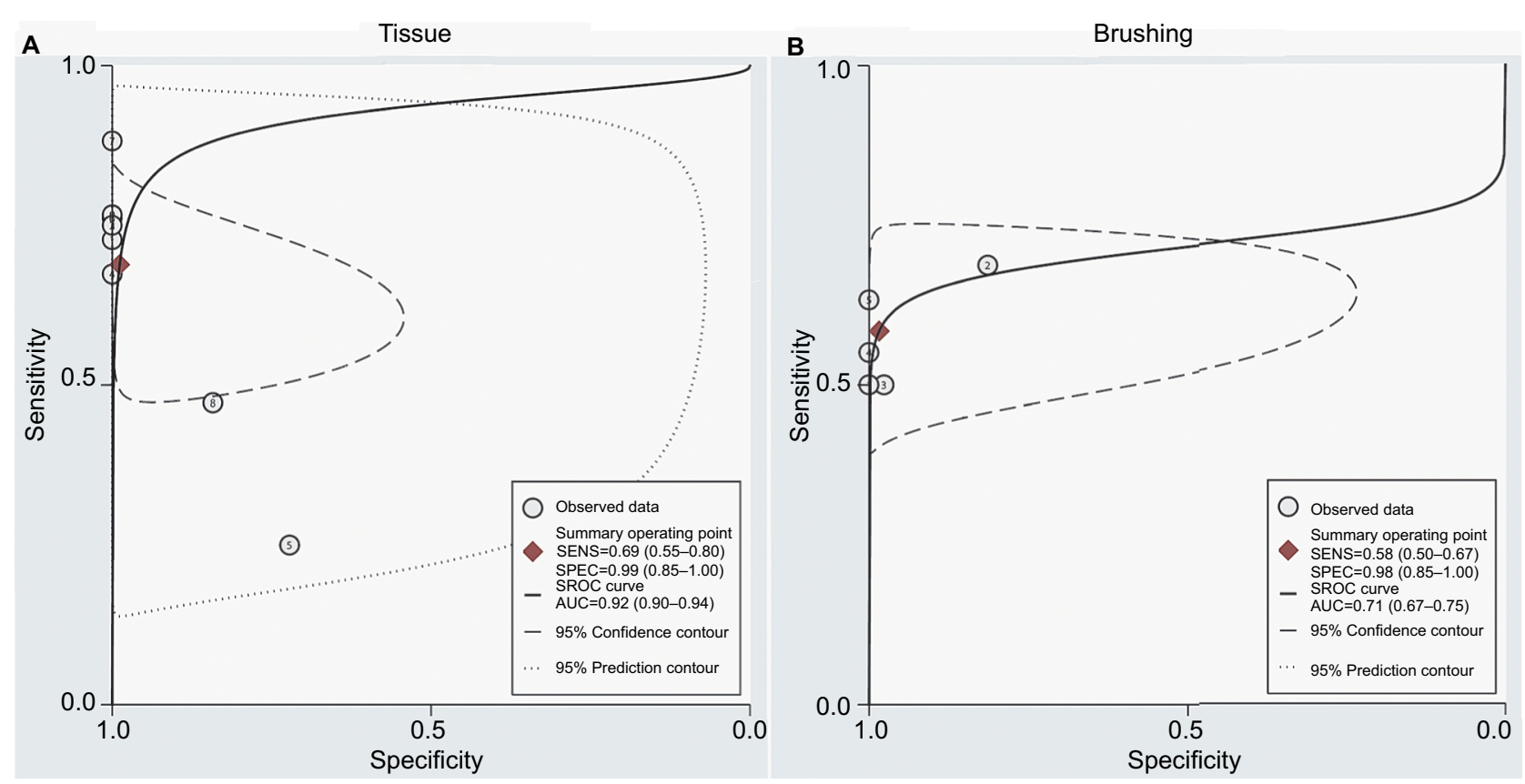

Figure 6 SROC plots with best fitting asymmetric curve of methylated DAPK for NPC by sample type.

Notes: (A) SROC plots with best fitting asymmetric curve of methylated DAPK for NPC by tissue sample; (B) SROC plots with best fitting asymmetric curve of methylated DAPK for NPC by brushing sample.

Abbreviations: SENS, sensitivity; SPEC, specificity; SROC, summary of receiver-operator characteristic; NPC, nasopharyngeal carcinoma; AUC, area under the receiver operating characteristic curve.
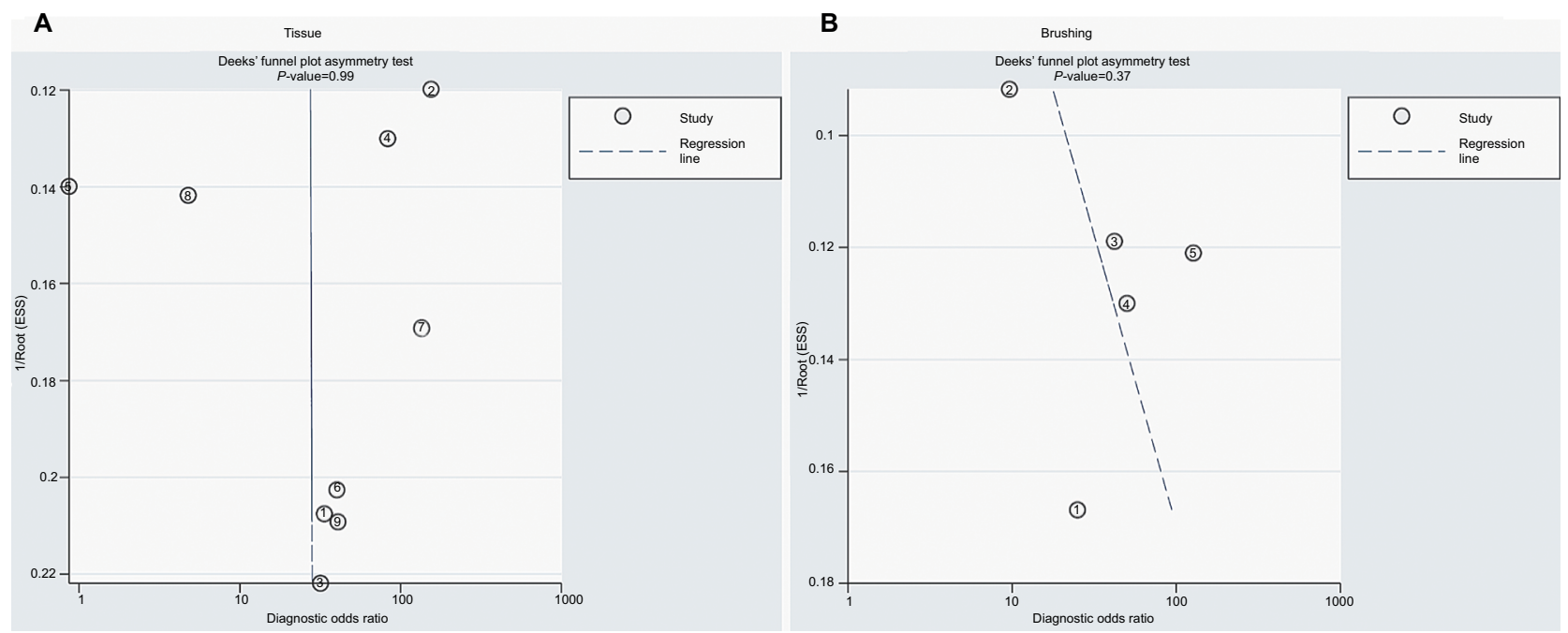

Figure 7 The publication bias of methylated DAPK for diagnosis of NPC by sample type.

Notes: (A) The publication bias of methylated DAPK for diagnosis of NPC by tissue sample. (B) The publication bias of methylated DAPK for diagnosis of NPC by brushing sample. Abbreviations: ESS, effective sample size; NPC, nasopharyngeal carcinoma.

Arctic region, with incidence rates up to 30 per 100,000 persons. ${ }^{41}$ However, even within Asian populations, dramatic differences in NPC incidence are observed across regions. Higher incidences of NPC are found in urban areas than in rural areas. ${ }^{42}$

Although multiple specific environmental factors, including early exposure to salted food and latent EBV infection, have been suggested to be risk factors in the endemic regions, the predisposition to NPC among southern Chinese popula- tion strongly suggests the involvement of both genetic and epigenetic susceptibility and environmental factors. ${ }^{43,44}$ Genome-wide linkage analyses of high-risk Chinese NPC identified several candidate NPC susceptibility loci, including chromosome 3p21.44,45 Many TSGs, such as RASSF1A and $M L H 1$, have been isolated from this region. ${ }^{46,47}$ Inactivation of multiple TSGs attributed to high frequencies of deletion of this region has been associated with the progression of NPC..$^{14,48}$ Additionally, aberrant methylation of the $5^{\prime} \mathrm{CpG}$ 
A

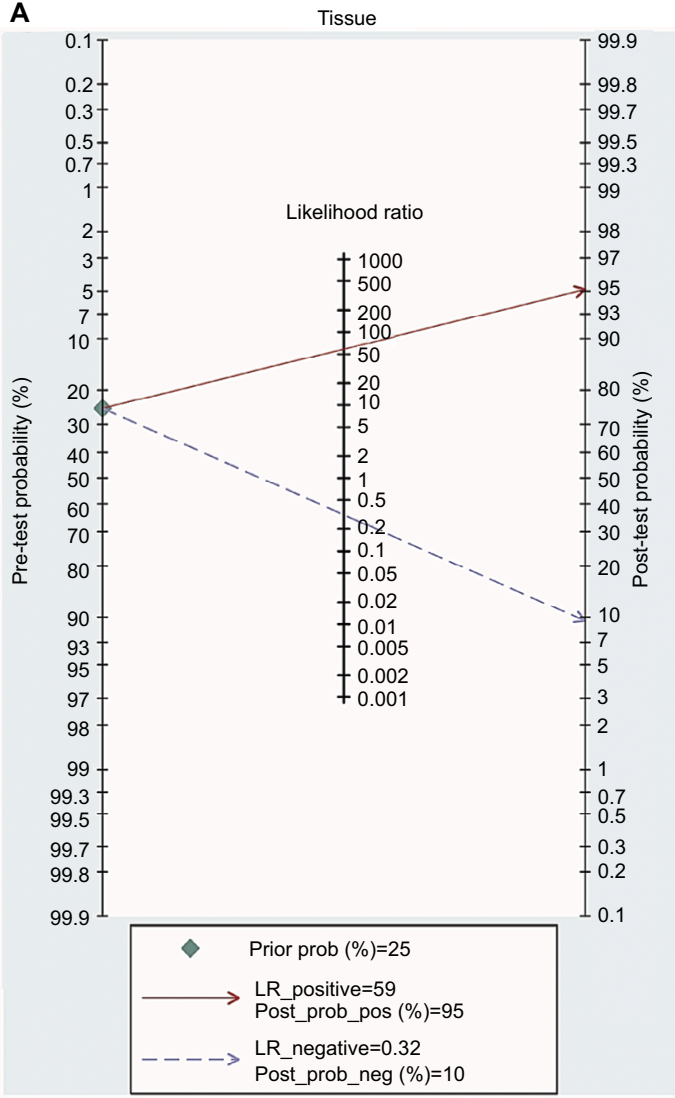

C

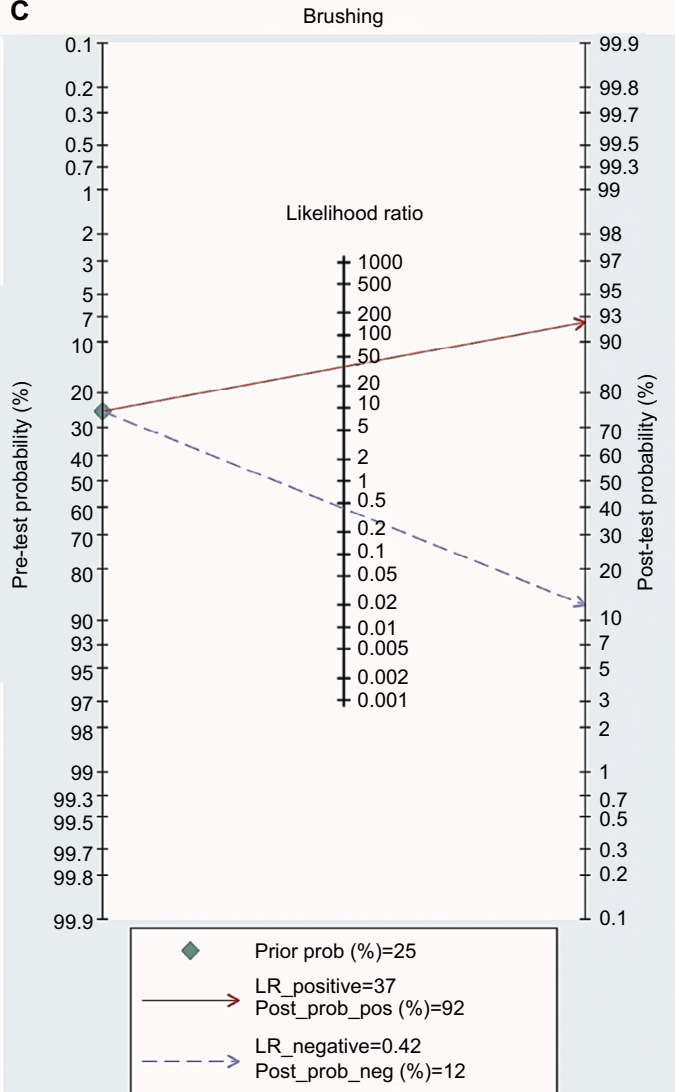

B

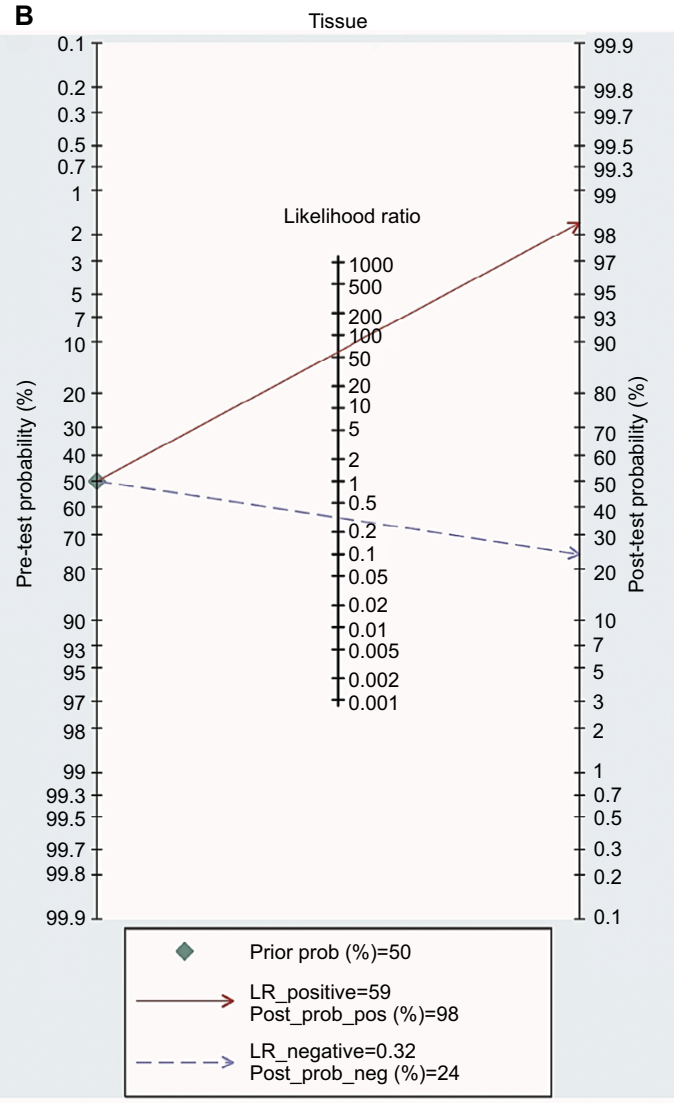

D

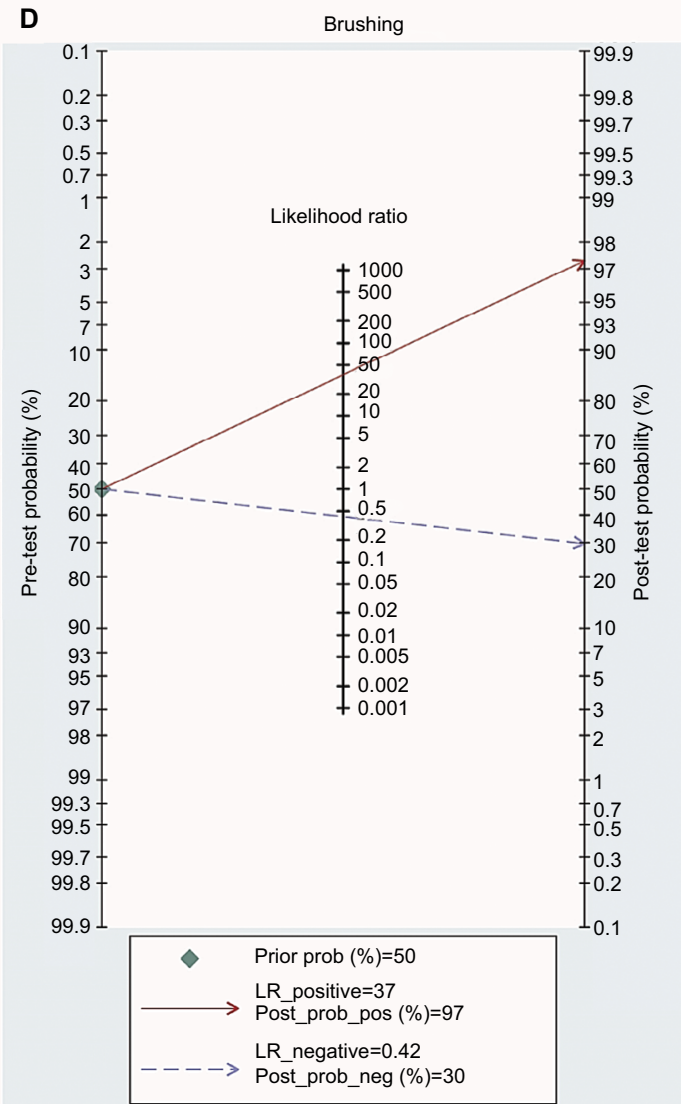

Figure 8 Fagan plots analysis to illustrate the clinical utility of methylated DAPK for identification of NPC by sample type.

Notes: (A) The post-test probability of NPC was $95 \%$ at a pretest probability of $25 \%$ by tissue samples. (B) The post-test probability of NPC was $98 \%$ at a pretest probability of $50 \%$ by tissue samples. (C) The post-test probability of NPC was $92 \%$ at a pretest probability of $25 \%$ by brushing sample. (D) The post-test probability of NPC was $97 \%$ at a pretest probability of $50 \%$ by brushing sample. 
island is also a major mechanism for the silencing of these genes. $^{49-51}$

DNA methylation is the process of formation of methylcytosine in DNA by the addition of a methyl group to a cytosine. ${ }^{52}$ Neoplastic cells simultaneously harbor widespread genomic hypomethylation and more regional areas of hypermethylation. Each component of methylation imbalance may contribute to tumor progression. ${ }^{53,54}$ Hypermethylation of gene promoter regions is associated with gene repression and can be considered an alternative modification to coding mutations that induces the inactivation of TSGs (such as P16INK4a, MGMT, GSTP1, and APC) in numerous human cancers. ${ }^{55-58}$ The dysregulation of TSGs resulting in the imbalance of biological process and uncontrolled cell proliferation is contributed to the transformation of neoplastic cell. ${ }^{59}$ Among these abnormal methylated genes in human cancers, the hypermethylation of $C D K N 2 A$ is well characterized that is involved in tumorigenesis by inducing the loss of negative regulator of cell proliferation. ${ }^{60}$ Besides, the identities of the hypermethylated regions can vary between cancer types. ${ }^{61}$ The use of the hypermethylation events of $M G M T$ in glioma and GSTP1 in prostate cancer ${ }^{62}$ is effective for diagnosis of cancer, indicating that alterations of epigenetic markers could be used as cancer biomarkers.

DAPK, encoded by the DAPK gene, belongs to the DAPK family. The DAPK family contains three closely related serine/threonine kinases, named DAPK, ZIPK, and DRP$1 .{ }^{21}$ Several lines of evidence indicate that the most studied member of the DAPK family, $D A P K$, has tumor and metastasis suppressor properties. ${ }^{26,63}$ DAPK downregulation or inactivation through epigenetic modification, especially DNA methylation, has been observed in a number of metastatic cancers. ${ }^{64,65}$ The imbalance of proliferation and apoptosis, partly induced by the inactivation of the apoptotic pathway, has been considered as one of the hallmarks of cancer, specifically the initiation and progression of human cancers, including NPC. ${ }^{66}$ The dysfunction of apoptosis-related genes could decrease apoptosis induced by chemotherapy. Thus, the inactivation of the apoptotic pathway by aberrant methylation has been associated with chemoresistance.$^{67,68}$ As an important member of the apoptotic pathway, the role of abnormal hypermethylation of $D A P K$ in NPC has been investigated by many researchers. ${ }^{31-36}$ The detection of $D A P K$ methylation in different NPC patients may be one reason for the inconsistent conclusions about the association between $D A P K$ methylation and the risk of NPC. ${ }^{33,35}$ To solve this problem, we performed a meta-analysis and conducted a subgroup analysis by sample source, and our results support the correlation between hypermethylated $D A P K$ and increased risk of NPC, which was also confirmed by subgroup analysis of sample type. Moreover, the pooled OR in brushing samples was close to that in tissue samples, indicating that the detection of methylated $D A P K$ in brushing samples could serve as an important alternative non-invasion measurement for diagnosis of NPC. Traditional diagnosis of NPC is made by biopsy of the nasopharyngeal mass. Fused positron emission tomography/computed tomography is a valuable imaging tool in patients for staging diagnosis of NPC. However, NPC is commonly diagnosed late due to its deep location and vague symptoms. ${ }^{69}$ Thus, by measuring the nuclear DNA content, DNA diploidy was found to occur earlier in the progression from premalignant to malignant head and neck squamous cell carcinomas (including NPC). However, the diagnostic strength of methylated $D A P K$ has not been investigated in NPC.

The current study aims to demonstrate that methylation of $D A P K$ was readily applicable for routine diagnostic work. Therefore, diagnostic meta-analyses were performed in brushing samples and tissue samples separately to assess the power of methylated $D A P K$ in distinguishing NPC from control tissue. Since the minimum number of included studies for a diagnostic meta-analysis is four, the diagnostic strength of methylated $D A P K$ in blood samples was unable to be evaluated. The summary specificity and sensitivity of methylated $D A P K$ for tissue samples were 0.99 and 0.69 , respectively, and for brushing samples, they were 0.98 and 0.58 , respectively, which shows the non-inferior effect for early monitoring of NPC in brushing samples. Fagan plots were drawn based on the values of PLR and NLR to assess the clinical utility of methylated $D A P K$. The Fagan plot is calculated based on Bayes' rule, which is used to formalize how the pre-test probability of the risk of NPC is changed by the detection of methylated $D A P K$ to yield the post-test probability of the risk of NPC. ${ }^{30}$ From our results, in both diagnostic meta-analyses, the post-test probability of NPC risk increased to more than $90 \%$ when an individual with $25 \%$ of pre-test probability of NPC had a positive result of $D A P K$ methylation. For the exclusion diagnosis, the post-test probability of NPC risk decreased to less than $30 \%$ when an individual with the $50 \%$ pre-test probability of NPC had a negative result of $D A P K$ methylation. According to the results of this diagnostic meta-analysis, the detection of methylated $D A P K$ in brushing samples for distinguishing NPC from non-tumor samples could serve as an alternative non-invasive biomarker.

In summary, this integrated analysis demonstrated the correlation of methylated DAPK and increased risk of NPC. 
In addition, the detection of methylated $D A P K$ in brushing samples of NPC could serve as a promising alternative measurement for monitoring the initiation of NPC. Welldesigned prospective studies with larger sample sizes will be indispensable to confirm our results.

\section{Acknowledgments}

This research was supported by grants from the National Natural Science Foundation of China (no. 81670920), Zhejiang Provincial Natural Science Foundation of China (nos. LY14H160003, LY15H130003), the Scientific Innovation Team Project of Ningbo (no. 2012B82019), Ningbo Social Developmental Key Research Project (no. 2012C5015), Medical and Health Research Project of Zhejiang Province (nos. 2014PYA017; 2012ZDA042; 2017KY133), Ningbo Health Branding Subject Fund (no. PPXK2018-02), and Ningbo Natural Science Foundation (nos. 2012A610208; 2017A610236, 2015A610221).

\section{Disclosure}

The authors report no conflicts of interest in this work.

\section{References}

1. Luo J, Chia KS, Chia SE, Reilly M, Tan CS, Ye W. Secular trends of nasopharyngeal carcinoma incidence in Singapore, Hong Kong and Los Angeles Chinese populations, 1973-1997. Eur J Epidemiol. 2007;22(8):513-521.

2. Chen W, Zheng R, Baade PD, et al. Cancer statistics in China, 2015. CA Cancer J Clin. 2016;66(2):115-132.

3. Ghosh SK, Singh AS, Mondal R, Kapfo W, Khamo V, Singh YI. Dysfunction of mitochondria due to environmental carcinogens in nasopharyngeal carcinoma in the ethnic group of Northeast Indian population. Tumour Biol. 2014;35(7):6715-6724.

4. Tsao SW, Yip YL, Tsang CM, et al. Etiological factors of nasopharyngeal carcinoma. Oral Oncol. 2014;50(5):330-338.

5. Belbaraka R, Lalya I, Boulaamane L, Tazi M, Benjaafar N, Errihani H. Les facteurs de risque alimentaires du carcinome indifférencié du nasopharynx: Une étude cas témoin. [Dietary risk factors of undifferenced nasopharyngeal carcinoma: a case-control study]. Tunis Med. 2013;91(6):406-409. French [with English abstract].

6. Gallicchio L, Matanoski G, Tao XG, et al. Adulthood consumption of preserved and nonpreserved vegetables and the risk of nasopharyngeal carcinoma: a systematic review. Int J Cancer. 2006;119(5): 1125-1135.

7. Jia WH, Luo XY, Feng BJ, et al. Traditional Cantonese diet and nasopharyngeal carcinoma risk: a large-scale case-control study in Guangdong, China. BMC Cancer. 2010;10:446.

8. Fachiroh J, Sangrajrang S, Johansson M, et al. Tobacco consumption and genetic susceptibility to nasopharyngeal carcinoma (NPC) in Thailand. Cancer Causes Control. 2012;23(12):1995-2002.

9. Xue WQ, Qin HD, Ruan HL, Shugart YY, Jia WH. Quantitative association of tobacco smoking with the risk of nasopharyngeal carcinoma: a comprehensive meta-analysis of studies conducted between 1979 and 2011. Am J Epidemiol. 2013;178(3):325-338.

10. Chen L, Gallicchio L, Boyd-Lindsley K, et al. Alcohol consumption and the risk of nasopharyngeal carcinoma: a systematic review. Nutr Cancer. 2009;61(1):1-15.
11. Ruan HL, Xu FH, Liu WS, et al. Alcohol and tea consumption in relation to the risk of nasopharyngeal carcinoma in Guangdong, China. Front Med China. 2010;4(4):448-456.

12. Chen CY, Huang KY, Shen JH, Tsao KC, Huang YC. A large-scale seroprevalence of Epstein-Barr virus in Taiwan. PLoS One. 2015;10(1):e0115836.

13. Dowd JB, Palermo T, Brite J, McDade TW, Aiello A. Seroprevalence of Epstein-Barr virus infection in U.S. children ages 6-19, 2003-2010. PLoS One. 2013;8(5):e64921.

14. Hui AB, Lo KW, Leung SF, et al. Detection of recurrent chromosomal gains and losses in primary nasopharyngeal carcinoma by comparative genomic hybridisation. Int J Cancer. 1999;82(4):498-503.

15. Lo KW, Huang DP. Genetic and epigenetic changes in nasopharyngeal carcinoma. Semin Cancer Biol. 2002;12(6):451-462.

16. Lo KW, Teo PM, Hui AB, et al. High resolution allelotype of microdissected primary nasopharyngeal carcinoma. Cancer Res. 2000;60(13):3348-3353.

17. Kwong J, Lo KW, To KF, Teo PM, Johnson PJ, Huang DP. Promoter hypermethylation of multiple genes in nasopharyngeal carcinoma. Clin Cancer Res. 2002;8(1):131-137.

18. Rountree MR, Bachman KE, Herman JG, Baylin SB. DNA methylation, chromatin inheritance, and cancer. Oncogene. 2001;20(24):3156-3165.

19. Brooks JD, Weinstein M, Lin X, et al. CG island methylation changes near the GSTP1 gene in prostatic intraepithelial neoplasia. Cancer Epidemiol Biomarkers Prev. 1998;7(6):531-536.

20. Lamy A, Sesboüé R, Bourguignon J, et al. Aberrant methylation of the CDKN2a/p16INK4a gene promoter region in preinvasive bronchial lesions: a prospective study in high-risk patients without invasive cancer. Int J Cancer. 2002;100(2):189-193.

21. Feinstein E, Druck T, Kastury K, et al. Assignment of DAP1 and DAPK - genes that positively mediate programmed cell death triggered by IFN-gamma - to chromosome regions 5p12.2 and 9q34.1, respectively. Genomics. 1995;29(1):305-307.

22. Dansranjavin T, Möbius C, Tannapfel A, et al. E-cadherin and DAP kinase in pancreatic adenocarcinoma and corresponding lymph node metastases. Oncol Rep. 2006;15(5):1125-1131.

23. Inbal B, Cohen O, Polak-Charcon S, et al. DAP kinase links the control of apoptosis to metastasis. Nature. 1997;390(6656):180-184.

24. Katzenellenbogen RA, Baylin SB, Herman JG. Hypermethylation of the DAP-kinase $\mathrm{CpG}$ island is a common alteration in B-cell malignancies. Blood. 1999;93(12):4347-4353.

25. Kissil JL, Feinstein E, Cohen O, et al. DAP-kinase loss of expression in various carcinoma and B-cell lymphoma cell lines: possible implications for role as tumor suppressor gene. Oncogene. 1997;15(4):403-407.

26. Fendri A, Masmoudi A, Khabir A, et al. Inactivation of RASSF1A, RARbeta2 and DAP-kinase by promoter methylation correlates with lymph node metastasis in nasopharyngeal carcinoma. Cancer Biol Ther. 2009;8(5):444-451.

27. Nawaz I, Moumad K, Martorelli D, et al. Detection of nasopharyngeal carcinoma in Morocco (North Africa) using a multiplex methylationspecific PCR biomarker assay. Clin Epigenetics. 2015;7:89.

28. Coory MD. Comment on: Heterogeneity in meta-analysis should be expected and appropriately quantified. Int J Epidemiol. 2010;39(3):932; author reply 933.

29. Jackson D. The power of the standard test for the presence of heterogeneity in meta-analysis. Stat Med. 2006;25(15):2688-2699.

30. Hellmich M, Lehmacher W. A ruler for interpreting diagnostic test results. Methods Inf Med. 2005;44(1):124-126.

31. Tian F, Yip SP, Kwong DL, Lin Z, Yang Z, Wu VW. Promoter hypermethylation of tumor suppressor genes in serum as potential biomarker for the diagnosis of nasopharyngeal carcinoma. Cancer Epidemiol. 2013;37(5):708-713.

32. Wong TS, Kwong DL, Sham JS, Wei WI, Kwong YL, Yuen AP. Quantitative plasma hypermethylated DNA markers of undifferentiated nasopharyngeal carcinoma. Clin Cancer Res. 2004;10(7):2401-2406.

33. Yang X, Dai W, Kwong DL, et al. Epigenetic markers for noninvasive early detection of nasopharyngeal carcinoma by methylation-sensitive high resolution melting. Int J Cancer. 2015;136(4):E127-E135. 
34. Tong JH, Tsang RK, Lo KW, et al. Quantitative Epstein-Barr virus DNA analysis and detection of gene promoter hypermethylation in nasopharyngeal (NP) brushing samples from patients with NP carcinoma. Clin Cancer Res. 2002;8(8):2612-2619.

35. Chang HW, Chan A, Kwong DL, Wei WI, Sham JS, Yuen AP. Evaluation of hypermethylated tumor suppressor genes as tumor markers in mouth and throat rinsing fluid, nasopharyngeal swab and peripheral blood of nasopharygeal carcinoma patient. Int J Cancer. 2003;105(6): 851-855.

36. Zhang Z, Sun D, Hutajulu SH, et al. Development of a non-invasive method, multiplex methylation specific PCR (MMSP), for early diagnosis of nasopharyngeal carcinoma. PLoS One. 2012;7(11):e45908.

37. Challouf S, Ziadi S, Zaghdoudi R, Ksiaa F, Ben Gacem R, Trimeche M. Patterns of aberrant DNA hypermethylation in nasopharyngeal carcinoma in Tunisian patients. Clin Chim Acta. 2012;413(7-8):795-802.

38. Kong WJ, Zhang S, Guo CK, et al. Effect of methylation-associated silencing of the death-associated protein kinase gene on nasopharyngeal carcinoma. Anticancer Drugs. 2006;17(3):251-259.

39. Liang H, Li L, Chen Q, Li X. [Methylation of DAPK gene promoter in nasopharyngeal carcinoma]. Mod Oncol. 2015;9:1213-1215. Chinese.

40. Wong TS, Chang HW, Tang KC, et al. High frequency of promoter hypermethylation of the death-associated protein-kinase gene in nasopharyngeal carcinoma and its detection in the peripheral blood of patients. Clin Cancer Res. 2002;8(2):433-437.

41. Forman D, Bray F, Brewster DH, et al. Cancer Incidence in Five Continents, Volume X. IARC Scientific Publication No. 164. Lyon: International Agency for Research on Cancer; 2013. Available from: http://www. iarc.fr/en/publications/pdfs-online/epi/sp164/. Accessed July 30, 2018.

42. Wei KR, Zheng RS, Zhang SW, Liang ZH, Li ZM, Chen WQ. Nasopharyngeal carcinoma incidence and mortality in China, 2013. Chin J Cancer. 2017;36(1):90.

43. Friborg J, Wohlfahrt J, Melbye M. Familial risk and clustering of nasopharyngeal carcinoma in Guangdong, China. Cancer. 2005;103(1):211; author reply 211-212.

44. Xiong W, Zeng ZY, Xia JH, et al. A susceptibility locus at chromosome 3p21 linked to familial nasopharyngeal carcinoma. Cancer Res. 2004;64(6):1972-1974.

45. Feng BJ, Huang W, Shugart YY, et al. Genome-wide scan for familial nasopharyngeal carcinoma reveals evidence of linkage to chromosome 4. Nat Genet. 2002;31(4):395-399.

46. Dammann R, Li C, Yoon JH, Chin PL, Bates S, Pfeifer GP. Epigenetic inactivation of a RAS association domain family protein from the lung tumour suppressor locus 3p21.3. Nat Genet. 2000;25(3):315-319.

47. Hemminki A, Peltomäki P, Mecklin JP, et al. Loss of the wild type MLH1 gene is a feature of hereditary nonpolyposis colorectal cancer. Nat Genet. 1994;8(4):405-410.

48. Lo K, Tsao S, Leung S, Choi P, Lee J, Huang D. Detailed deletion mapping on the short arm of chromosome-3 in nasopharyngeal carcinomas. Int J Oncol. 1994;4(6):1359-1364.

49. Capel E, Fléjou JF, Hamelin R. Assessment of MLH1 promoter methylation in relation to gene expression requires specific analysis. Oncogene. 2007;26(54):7596-7600.

50. Morrissey C, Martinez A, Zatyka M, et al. Epigenetic inactivation of the RASSF1A 3p21.3 tumor suppressor gene in both clear cell and papillary renal cell carcinoma. Cancer Res. 2001;61(19):7277-7281.
51. Wagner KJ, Cooper WN, Grundy RG, et al. Frequent RASSF1A tumour suppressor gene promoter methylation in Wilms' tumour and colorectal cancer. Oncogene. 2002;21(47):7277-7282.

52. Baylin SB, Herman JG, Graff JR, Vertino PM, Issa JP. Alterations in DNA methylation: a fundamental aspect of neoplasia. Adv Cancer Res. 1998;72:141-196.

53. Baylin SB, Makos M, Wu JJ, et al. Abnormal patterns of DNA methylation in human neoplasia: potential consequences for tumor progression. Cancer Cells. 1991;3(10):383-390.

54. Nass SJ, Herman JG, Gabrielson E, et al. Aberrant methylation of the estrogen receptor and $\mathrm{E}-$ cadherin $^{\prime}{ }^{\prime} \mathrm{CpG}$ islands increases with malignant progression in human breast cancer. Cancer Res. 2000;60(16):4346- 4348.

55. Calmon MF, Colombo J, Carvalho F, et al. Methylation profile of genes CDKN2A (p14 and p16), DAPK1, CDH1, and ADAM23 in head and neck cancer. Cancer Genet Cytogenet. 2007;173(1):31-37.

56. Gerson SL. MGMT: its role in cancer aetiology and cancer therapeutics. Nat Rev Cancer. 2004;4(4):296-307.

57. Millar DS, Ow KK, Paul CL, Russell PJ, Molloy PL, Clark SJ. Detailed methylation analysis of the glutathione S-transferase pi (GSTP1) gene in prostate cancer. Oncogene. 1999;18(6):1313-1324.

58. Tsuchiya T, Tamura G, Sato K, et al. Distinct methylation patterns of two APC gene promoters in normal and cancerous gastric epithelia. Oncogene. 2000;19(32):3642-3646.

59. Evan GI, Vousden KH. Proliferation, cell cycle and apoptosis in cancer. Nature. 2001;411:342.

60. Trzeciak L, Hennig E, Kolodziejski J, Nowacki M, Ostrowski J. Mutations, methylation and expression of CDKN2a/p16 gene in colorectal cancer and normal colonic mucosa. Cancer Lett. 2001;163(1): $17-23$.

61. Costello JF, Fruhwald MC, Smiraglia DJ, et al. Aberrant CpG-island methylation has non-random and tumour-type-specific patterns. Nat Genet. 2000;24(2):132-138.

62. Esteller M, Corn PG, Urena JM, Gabrielson E, Baylin SB, Herman JG. Inactivation of glutathione S-transferase P1 gene by promoter hypermethylation in human neoplasia. Cancer Res. 1998;58(20): 4515-4518.

63. Chen HY, Lee YR, Chen RH. The functions and regulations of DAPK in cancer metastasis. Apoptosis. 2014;19(2):364-370.

64. Fischer JR, Ohnmacht U, Rieger N, et al. Promoter methylation of RASSF1A, RARbeta and DAPK predict poor prognosis of patients with malignant mesothelioma. Lung Cancer. 2006;54(1):109-116.

65. Mittag F, Kuester D, Vieth M, et al. DAPK promotor methylation is an early event in colorectal carcinogenesis. Cancer Lett. 2006;240(1): 69-75.

66. Hanahan D, Weinberg RA. The hallmarks of cancer. Cell. 2000;100(1): $57-70$.

67. Ishiguro $\mathrm{M}$, Iida $\mathrm{S}$, Uetake $\mathrm{H}$, et al. Effect of combined therapy with low-dose 5-aza-2'-deoxycytidine and irinotecan on colon cancer cell line HCT-15. Ann Surg Oncol. 2007;14(5):1752-1762.

68. Teodoridis JM, Strathdee G, Brown R. Epigenetic silencing mediated by $\mathrm{CpG}$ island methylation: potential as a therapeutic target and as a biomarker. Drug Resist Updat. 2004;7(4-5):267-278.

69. Chen YK, Su CT, Ding HJ, et al. Clinical usefulness of fused PET/CT compared with PET alone or CT alone in nasopharyngeal carcinoma patients. Anticancer Res. 2006;26(2B):1471-1477.
Cancer Management and Research

\section{Publish your work in this journal}

Cancer Management and Research is an international, peer-reviewed open access journal focusing on cancer research and the optimal use of preventative and integrated treatment interventions to achieve improved outcomes, enhanced survival and quality of life for the cancer patient. The manuscript management system is completely online and includes
Dovepress

a very quick and fair peer-review system, which is all easy to use. Visit http://www.dovepress.com/testimonials.php to read real quotes from published authors. 